\title{
Relating Water Deficiency to Berry Texture, Skin Cell Wall Composition, and Expression of Remodeling Genes in Two Vitis vinifera L. Varieties
}

\author{
J. C. Fernandes, ${ }^{\dagger}$ F. Cobb, ${ }^{\dagger}{ }^{\S}$ S. Tracana, ${ }^{\dagger}$ G. J. Costa, ${ }^{\dagger}$ I. Valente, ${ }^{\dagger}$ L. F. Goulao, ${ }^{\ddagger}$ and S. Amâncio ${ }^{*}{ }^{\dagger}$ \\ ${ }^{\dagger}$ DRAT/LEAF, Instituto Superior de Agronomia, Universidade de Lisboa, Tapada da Ajuda, 1349-017 Lisbon, Portugal \\ *BioTrop, Instituto de Investigação Científica Tropical (IICT, IP), Pólo Mendes Ferrão - Tapada da Ajuda, 1349-017 Lisbon, \\ Portugal
}

Supporting Information

\begin{abstract}
The cell wall (CW) is a dynamic structure that responds to stress. Water shortage (WS) impacts grapevine berry composition and its sensorial quality. In the present work, berry texture, skin CW composition, and expression of remodeling genes were investigated in two $V$. vinifera varieties, Touriga Nacional (TN) and Trincadeira (TR), under two water regimes, Full Irrigation (FI) and No Irrigation (NI). The global results allowed an evident separation between both varieties and the water treatments. WS resulted in increased anthocyanin contents in both varieties, reduced amounts in cellulose and lignin at maturation, but an increase in arabinose-containing polysaccharides more tightly bound to the CW in TR. In response to WS, the majority of the $\mathrm{CW}$ related genes were down-regulated in a variety dependent pattern. The results support the assumption that WS affects grape berries by stiffening the CW through alteration in pectin structure, supporting its involvement in responses to environmental conditions.
\end{abstract}

KEYWORDS: cell wall, gene expression, texture, V. vinifera, water stress

\section{INTRODUCTION}

Grapevines (Vitis vinifera L.) are one of the most important crops worldwide. About $80 \%$ of grapes cultivated are used in winemaking, ${ }^{1}$ but this species is also used to produce table grapes and raisins. Grapevines can be successfully grown in a range of different climates and management conditions, whose practices have been adapted to cope to each particular environment aiming at improved yields with adequate quality of the final product. Global climate changes are exacerbating problems associated with water deficit and high evapotranspiration rates that are likely to affect berry development, yield, and ultimately wine quality. Much of the grape berry sensorial characteristics, health benefits, and quality for wine making are due to the presence of acids, anthocyanins, tannins, and other phenolic compounds generally located in their skin cells ${ }^{2,3}$ and whose accumulation is also dependent on the growing climatic conditions. Phenolic compounds are known to interact with the plant cell wall (CW) polysaccharides, so a role in polyphenol accessibility has been proposed. ${ }^{4}$

For those reasons, understanding the $\mathrm{CW}$ changes that occur in grape skins during the berry development and softening has considerable importance in enology. ${ }^{5}$

Grape berries follow three distinct phases of development during their double sigmoidal growth curve. Phase I is due to cell division and enlargement and is followed by a phase II characterized by the absence of changes in berry weight and volume, ending with the onset of ripening (veraison). After this lag phase, a second growth phase (phase III) occurs in which an increase in size of the central mesocarp cells is observed, resulting from cell expansion within the berry. The ripening represents the last third of berry development, where softening and expansion occurs simultaneously, and is accompanied by sugar accumulation and water influx. ${ }^{6}$ Both expansion and softening of the berry are modulated by modifications of its $\mathrm{CW}$ that include synthesis, disassembly, and rearrangements of linkages between its components. ${ }^{7} \mathrm{CW}$ remodeling provides flexibility to cell expansion, directly altering the texture and, indirectly, flavor and aromas. ${ }^{8}$ Postveraison corresponds to the stage where most of the skin $\mathrm{CW}$ modifications occur, although depending on grape variety or abiotic conditions. 9 Some authors report a decrease in CW material accompanied by a thinning of the CW skins throughout the berry maturation, ${ }^{10}$ but others report that the amount of CW polysaccharides remains constant, although some modifications were observed at the pectic fraction level. ${ }^{11}$

The mesocarp CW of the grapes is composed of approximately $90 \%$ by weight of polysaccharides and up to $10 \%$ of proteins, in a structure that is typical of a type-I CW mode $^{12}$ where cellulose and polygalacturonans account for $30-40 \% .{ }^{13,14}$ In the exocarp, polysaccharides account for $50 \%$ of the CW material, ${ }^{15}$ of which $30 \%$ are glycosyl residues with a composition similar to mesocarp walls, ${ }^{13,16}$ while $20 \%$ are pectins, mostly methyl esterified. ${ }^{13}$ The remaining part is composed by insoluble proanthocyanidins, structural proteins, $^{15}$ and lignin. ${ }^{17}$

Along berry development, a decrease of the molecular masses of both pectic and hemicellulosic polysaccharides and a

Received: October 29, 2014

Revised: March 31, 2015

Accepted: April 1, 2015

Published: April 1, 2015 
reduction amount in cellulose and total hemicelluloses are observed at veraison and proceed throughout the subsequent phases. ${ }^{18}$ In the pectic fraction, the total amount and neutral and acid sugars temporally increase form before veraison to veraison, decreasing rapidly in post veraison. ${ }^{18,19}$ Conversely, the neutral sugar content of the hemicellulosic fraction decreases from before veraison to veraison. During veraison, the neutral sugar composition of each fraction changes little. ${ }^{18}$ This result discloses a pattern of temporal modifications in grape berry softening from before veraison to veraison. ${ }^{18}$

Water is one of the most valued resources on the planet, and understanding the impact of water deficit on grape development is vital. Mechanisms to cope with drought such as stomata control or extensive root systems developed by the grapevine have been recognized. ${ }^{20}$ It is well documented that water stress affects the variation of sugar and phenolic contents. ${ }^{21-23}$ Although to a lower extent than shoot organs, berry growth is sensitive to water deficits, being arrested ${ }^{24}$ mainly at the mesocarp level, so that the seed and skin mass account more significantly for berry weight, ${ }^{25,26}$ leading to an irreversible reduction in berry size ${ }^{27,28}$ often with thicker exocarps.

Under water deficit conditions occurring either before or postveraison, the anthocyanin content in the grape skin increases in a cultivar-dependent pattern. ${ }^{29,30}$ In ripening Cabernet Sauvignon grapes, water deficit leads to an increase in sugar accumulation only if imposed before veraison, ${ }^{29}$ while in the red cultivar Shiraz, water deficit applied at postveraison leads to a reduction in sugar concentration and an increase in phenolic compounds content, except for anthocyanins. ${ }^{31}$ Despite that, moderate water stress may increase the extractability of the anthocyanins into wine; ${ }^{32}$ therefore establishing a balanced water regime is vital to attaining a quality wine.

Functional genomic resources for $V$. vinifera have proliferated rapidly in the recent years after genome sequencing, ${ }^{33,34}$ and such information has paved the way for large-scale studies of gene expression profiling during berry development. CW metabolism related genes were over-represented in gene clusters with significant differential expression in several development stages. ${ }^{35-40}$

In grapes, differences in $\mathrm{CW}$ composition ${ }^{4}$ and transcriptome ${ }^{41}$ were described between red wine varieties, advising investigating the behavior of different genetic backgrounds to understand physiological events and agronomic performances.

The goal of this research was to investigate the effect of nonirrigation versus irrigation practices on grape quality parameters, with emphasis on the berry skin CW in two Portuguese grape varieties, Touriga Nacional (TN) and Trincadeira (TR). Our hypothesis was to verify if the changes in berry composition due to water shortage were related with remodeling of skin CW. For that purpose, berry yield, chemical characteristics, and mechanical properties as well as skin CW composition and expression of key candidate genes associated with berry development and ripening were examined at two developmental moments, veraison and full maturation.

\section{MATERIALS AND METHODS}

Experimental Vineyard and Plant Material. The study was conducted in 2012, on a vineyard located at the Centro Experimental de Pegões, Portugal $\left(38^{\circ} 39^{\prime} 1^{\prime \prime} \mathrm{N} ; 8^{\circ} 38^{\prime} 42^{\prime \prime} \mathrm{W}\right)$. The climate in the vineyard is Mediterranean with Atlantic influence, summers with hot days and fresh nights, and mild winters (Figures S1 and S2). The soil is derived from podzols, with a sandy surface layer $(0.6-1.0 \mathrm{~m})$ and clay at $1 \mathrm{~m}$ depth. Mixed clones of Touriga Nacional and Trincadeira were established in 2002, both varieties grafted on 1103 Paulsen rootstock. The plants spaced $2.5 \mathrm{~m}$ between rows and $1 \mathrm{~m}$ within rows were trained on vertical trellis and uniformly pruned on a bilateral Royat Cordon, ca. 12 buds per vine. Two irrigation regimes were considered: rain fed, nonirrigation (NI), and full irrigation in which water was supplied according to the evapotranspiration (100\% ETc; FI, control). ETc was estimated from the reference evapotranspiration $\left(\mathrm{ET}_{0}\right)$, obtained in an automatic weather station located within the experimental vineyard as described in Lopes et al. ${ }^{42}$ Irrigation water was applied with drip emitters $\left(4.0 \mathrm{~L} \mathrm{~h}^{-1}\right.$ for FI) two per vine, positioned $30 \mathrm{~cm}$ from the vine trunk, and began on June 29. Relative soil humidity in the soil profile was measured with a Diviner 2000 capacitance probe (Sentek Environmental Technologies, Stepney, Australia) in vertical tubes at increments of $0.1 \mathrm{~m}$ from the soil surface to a depth of $1.0 \mathrm{~m}^{43}$ and assessed at plant level by predawn leaf water potential on the preselected plants as described by Scholander et al. ${ }^{44}$ Three plants in each treatment and plot were preselected for analysis in a total of six plants per water regime and variety. At veraison $(50 \%$ colored berries) on July 27 for TR and August 10 for TN and full maturation, the berries were pooled per water regime and variety and development stages (Figure S2). Berries were kept frozen from arrival from the field until further analyses.

Grape Berry Composition. Three samples of 100 berries were used for berry composition analysis per treatment and variety. After detaching the pedicels and acquiring the sample fresh weight, must volume, $\mathrm{pH}$, total soluble solids (TSS in ${ }^{\circ}$ Brix) and total acidity, skin anthocyanin content and total phenol index were assessed.

The must $\mathrm{pH}$ was measured with a calibrated $\mathrm{pH}$ meter at room temperature. TSS were quantified using an Atago Brix pocket refractometer. Total acidity was measured via titration with sodium hydroxide and expressed in $\mathrm{g} \mathrm{dm}^{-3}$ of tartaric acid. Color density is given as the sum of absorbances in a $1 \mathrm{~cm}$ pathway at 420,520 , and $620 \mathrm{~nm} .{ }^{45}$ For extracted anthocyanin content, the skins were treated by the method of Carbonneau and Champagnol. ${ }^{46}$ The skins were suspended in $96 \%$ ethanol buffered with tartaric acid solution $(\mathrm{pH}$ 3.6), and after $24 \mathrm{~h}$ of maceration at $37{ }^{\circ} \mathrm{C}$ the solution was centrifuged at $5000 \mathrm{~g}$ for $10 \mathrm{~min}$ for (1) the calculation of extracted anthocyanin concentration as quantified by the method of RibereauGayon and Stonestreet ${ }^{47}$ with the absorbances obtained at $520 \mathrm{~nm}$ converted from a standard curve prepared with malvidin 3-glucoside and (2) estimation of total phenol by absorbance in a $1 \mathrm{~cm}$ pathway at $280 \mathrm{~nm}^{48}$

Texture Analyses. Two compression tests were employed to address texture attributes. Skin firmness was measured using a penetration test carried out on the detached skin of 50 mature berries trapped between two perforated acrylic plates. Measurements were made using a TA-XT Texture Analyser equipped with a HDP/90 platform and a cylinder flat probe of $2 \mathrm{~mm} \varnothing$ (ref.:P/2), using a $5 \mathrm{~kg}$ load cell. ${ }^{49}$ Tests were performed at $1 \mathrm{~mm} \mathrm{~s}^{-1}$, and berry skin breaking force is expressed in Newtons (N). Berry texture analysis was carried out in 50 uniform mature berries. Measurements were made using a TA-XT Texture Analyser (Stable Micro Systems Ltd., UK) equipped with a HDP/90 platform and compression platens of $75 \mathrm{~mm} \varnothing$, using a $5 \mathrm{~kg}$ load cell. The force to deform $10 \%$ of the berry equatorial diameter was expressed in Newtons $(\mathrm{N}) .^{50}$

Cell Wall Analysis. Cell Wall Extraction. Ten grams of fresh skins were lyophilized and homogenized in liquid nitrogen and the $\mathrm{CW}$ extracted according to the method described by Talmadge et al. ${ }^{51}$ as per Fernandes et al. ${ }^{52}$

Cellulose and Lignin Quantification. Cellulose was quantified by the Updegraff ${ }^{53}$ method, using the hydrolytic conditions described by Saeman et al. ${ }^{54}$ and quantifying the released glucose by the anthrone method. ${ }^{55}$ Klason lignin was determined using the method described by Hatfield et al. ${ }^{56}$ The results are expressed as microgram per milligram of CW.

Cell Wall Fractionation and Monosaccharide Quantification. The fractionation of berry skin CW at maturation followed the method of Selvendran and O'Neill ${ }^{57}$ with minor modifications as in Fernandes et al. ${ }^{52}$ Total sugars and uronic acids were determined using the 
Table 1. Berry Composition Parameters (Mean \pm Standard Deviation) Measured at Veraison and Maturation for Touriga Nacional (TN) and Trincadeira (TR), under Fully Irrigated (FI) and Non Irrigated (NI) Conditions ${ }^{a}$

\begin{tabular}{|c|c|c|c|c|c|c|c|}
\hline & & & berry weight $(\mathrm{g})$ per 100 berries & $\begin{array}{c}\text { must volume }(\mathrm{mL}) \\
\text { berries }\end{array}$ & $\mathrm{pH}$ & $\begin{array}{l}\text { total soluble } \\
\text { solids }\end{array}$ & $\begin{array}{c}\text { total acidity }\left(\mathrm{g} \mathrm{L}^{-1} \text { of }\right. \\
\text { Ta })\end{array}$ \\
\hline \multirow[t]{4}{*}{ Veraison } & \multirow[t]{2}{*}{$\mathrm{TN}$} & FI & $126.83^{\mathrm{aA}} \pm 5.95$ & $78.83^{\mathrm{a}} \pm 8.89$ & $3.02^{A} \pm 0.16$ & $13.33^{A *} \pm 0.51$ & $13.00^{\mathrm{A}} \pm 1.88$ \\
\hline & & NI & $78.60^{\mathrm{A} *} \pm 0.0$ & $39.33^{\mathrm{A} *} \pm 3.06$ & $3.11^{\mathrm{A}} \pm 0.13$ & $12.67^{\mathrm{A} *} \pm 0.12$ & $11.55^{\mathrm{A} *} \pm 0.91$ \\
\hline & \multirow[t]{2}{*}{$\mathrm{TR}$} & FI & $125.93^{\mathrm{A}} \pm 12.17$ & $80.33^{\mathrm{A}} \pm 11.93$ & $3.00^{\mathrm{A}} \pm 0.21$ & $11.30^{\mathrm{A}} \pm 0.70$ & $13.90^{\mathrm{aA}} \pm 2.13$ \\
\hline & & NI & $105.33^{\mathrm{A}} \pm 6.35$ & $61.00^{\mathrm{A}} \pm 4.36$ & $2.87^{\mathrm{A}} \pm 0.08$ & $10.53^{\mathrm{A}} \pm 0.90$ & $17.50^{\mathrm{A}} \pm 0.74$ \\
\hline \multirow[t]{4}{*}{ Maturation } & \multirow[t]{2}{*}{$\mathrm{TN}$} & $\mathrm{FI}$ & $143.10^{\mathrm{a} *} \pm 4.88$ & $92.83^{\mathrm{a} *} \pm 2.36$ & $4.16 \pm 0.07$ & $22.20^{\mathrm{a} *} \pm 0.26$ & $2.70 \pm 0.15$ \\
\hline & & NI & $113.28 \pm 11.93$ & $64.00 \pm 11.03$ & $4.29 \pm 0.06$ & $20.23 \pm 0.84$ & $2.55 \pm 0.26$ \\
\hline & \multirow[t]{2}{*}{ TR } & FI & $217.60^{a} \pm 11.46$ & $134.33^{\mathrm{a}} \pm 11.02$ & $4.20 \pm 0.11$ & $20.60^{a} \pm 0.60$ & $3.05 \pm 0.23$ \\
\hline & & NI & $132.87 \pm 4.54$ & $83.67 \pm 6.66$ & $4.32 \pm 0.45$ & $19.33 \pm 0.45$ & $2.95 \pm 0.31$ \\
\hline
\end{tabular}

${ }^{a}$ Lower case letter indicates significant differences between treatments, capital letter indicates significant differences between stages and asterisk indicates significant differences between varieties, at $p<0.01$ significance.

phenol-sulfuric acid assay and the m-hydroxybiphenyl assay, ${ }^{58}$ respectively. Glucose and galacturonic acid were the corresponding standards. Neutral sugars were quantified by Gas Chromatography (GC) according to Albersheim et al. ${ }^{59}$ with minor adaptations ${ }^{52}$ using a Supelco SP-2330 $30 \mathrm{~m} \times 0.25 \mathrm{~mm} \times 0.20 \mu \mathrm{m}$ Capillary Column in a Varian $450-\mathrm{GC}$ fitted with flame-ionization detector. The temperature program consisted of $210{ }^{\circ} \mathrm{C}(6 \mathrm{~min}$ hold $)$ increased to 230 at $20^{\circ} \mathrm{C} /$


Pure rhamnose, fucose, arabinose, xylose, mannose, galactose, and glucose were used as monosaccharide standards and inositol as an internal standard. For data acquisition, the Galaxie Chromatography Software (Agilent, USA) was used.

Quantification of Gene Expression. RNA Extraction and CDNA Synthesis. Total RNA was extracted from $V$. vinifera berries using the Spectrum Plant Total RNA Kit (Sigma-Aldrich) with some modifications. Samples were ground in liquid nitrogen, and $400 \mathrm{mg}$ of the material was split into two eppendorf tubes, and $900 \mu \mathrm{L}$ lysis buffer was added per tube. ${ }^{60}$ After centrifugation $(10 \mathrm{~min})$, the combined supernatants were filtered using the necessary number of filtration columns. A total of $750 \mu \mathrm{L}$ of binding solution was added to each filtrate and passed through a single binding column. The RNA was then eluted using Milli- $Q$ water. RNA samples were further treated with RNase-free DNase I (Qiagen) according to the manufacturer protocol, and quantification was carried out in a Synergy HT Multiplate Reader, with Gene5 software, using a Take3Multi-Volume Plate (Bio-Tek Instruments Inc. Winooski, USA). For reverse transcription, the RevertAid reverse transcriptase priming with oligo$\mathrm{d}(\mathrm{T})$ kit was used (Thermo Scientific) according to the manufacturer's recommendations.

Quantification of Gene Expression by Quantitative PCR (RT$q P(R)$. For each $V$. vinifera cDNA sequence retrieved from public databases (Genoscope 12X (http://www.genoscope.cns.fr/spip/)), a set of specific primers (Table S1) was designed and used to amplify grapevine skin cDNA resulting from the transcription of $2 \mu \mathrm{g}$ of total RNA, using conventional PCR. When amplification confirmed the expression, the transcripts were quantified by real-time PCR (qPCR), performed in $20 \mu \mathrm{L}$ reaction volumes composed of cDNA derived from $2 \mu \mathrm{g}$ of RNA, $0.5 \mu \mathrm{M}$ gene-specific primers (Table S1), and SsoFast EvaGreen Supermixes (Bio-Rad, Hercules, CA) using an iQ5 Real-Time Thermal Cycler (BioRad, Hercules, CA). Reaction conditions for cycling were $95{ }^{\circ} \mathrm{C}$ for $3 \mathrm{~min}$ followed by 40 cycles at $95{ }^{\circ} \mathrm{C}$ for $10 \mathrm{~s}, 61^{\circ} \mathrm{C}$ for $25 \mathrm{~s}$, and $72{ }^{\circ} \mathrm{C}$ for $30 \mathrm{~s}$. Melting curves were generated in each case to confirm the amplification of single products and absence of primer dimerization. Each analysis was performed in triplicate reactions, each in three biologic replicates $(n=$ 9 , in which each replicate is the average of three technical measurements). The corresponding quantification cycles (Cq) obtained by the iQ5 optical system software (Bio-Rad, Hercules, CA) were exported to a MS Excel spreadsheet (Microsoft Inc.) for quantification. Cq values of each gene of interest were normalized with respect to actin (Act) and translation initiation factor eIF-3 subunit 4 (TIF) Cqs. ${ }^{61}$ Relative gene expression values in NI conditions are presented in heat maps, performed using the $\mathrm{MeV}$ software, ${ }^{62}$ as $\log 2$ fold-change values in relation to control conditions (FI).

Statistical and Principal Component Analysis. All data are presented as mean values \pm standard deviation (SD) of at least three biological replicates in each assay. The results were statistically evaluated by variance analysis (ANOVA) and post hoc Bonferroni test with a $p<0.01$ significance level to compare the meaning of each effect with the SigmaPlot (Systat Software Inc.) statistical package. The Pearson correlation coefficient was calculated to disclose correlations between texture and skin composition values.

Data from 50 individual attributes measured at maturation were standardized, and a pair-wised correlation matrix was calculated and subjected to eigenvalue decomposition to identify orthogonal components of the original matrix and generate a Principal Component Analysis (PCA) biplot, using the NTsys-PC version 2.20e software package. ${ }^{63}$ The weight of each character in sample separation was determined by calculating eigenvectors using the mean values of each treatment.

\section{RESULTS}

Composition of Grape Berries. A first indication of the effect of stress imposition (rain fed, Non Irrigation (NI) compared with Full Irrigation (FI), control; Figure S1) on the $V$. vinifera berries was gained through the measurement of berry composition. NI treatment decreased berry weight and must volume in all cases and increased TSS at maturity in both varieties, as shown in Table 1, although it was more pronounced in $\mathrm{TN}$ at veraison and in TR at maturation. At veraison under a water deficit, total acidity was significantly different between varieties. However, TR was delayed comparing to $\mathrm{TN}$ in either sugar increase or acid decrease (Table 1). Furthermore, we observed that in $\mathrm{TN}$, water shortage (TN-NI) induced anthocyanin accumulation, while in $\mathrm{TR}$, higher anthocyanin content was observed at maturity in the absence of water shortage (Figure 1A). The total phenol index followed the same pattern except for a slight increase at veraison in TR-NI (Figure 1B). The color is one of the most important characteristics for a wine. At maturation the water shortage induces a more intense color in the berry skin, which was more intense in TN berries (Figure 1C).

Cellulose and Lignin Content. The cellulose content of TN berry skins was not affected by the water regime, whether in veraison or in maturation. However, in TR, a statistically significant decrease was observed in NI between veraison and maturation and, at maturation, between control and NI (Figure $2 \mathrm{~A}$ ). Following the same pattern, lignin decreased in TR-NI at maturation (Figure 2B).

Berry Texture. Alterations in berry firmness can be addressed by measuring changes in compression, while skin break force is 


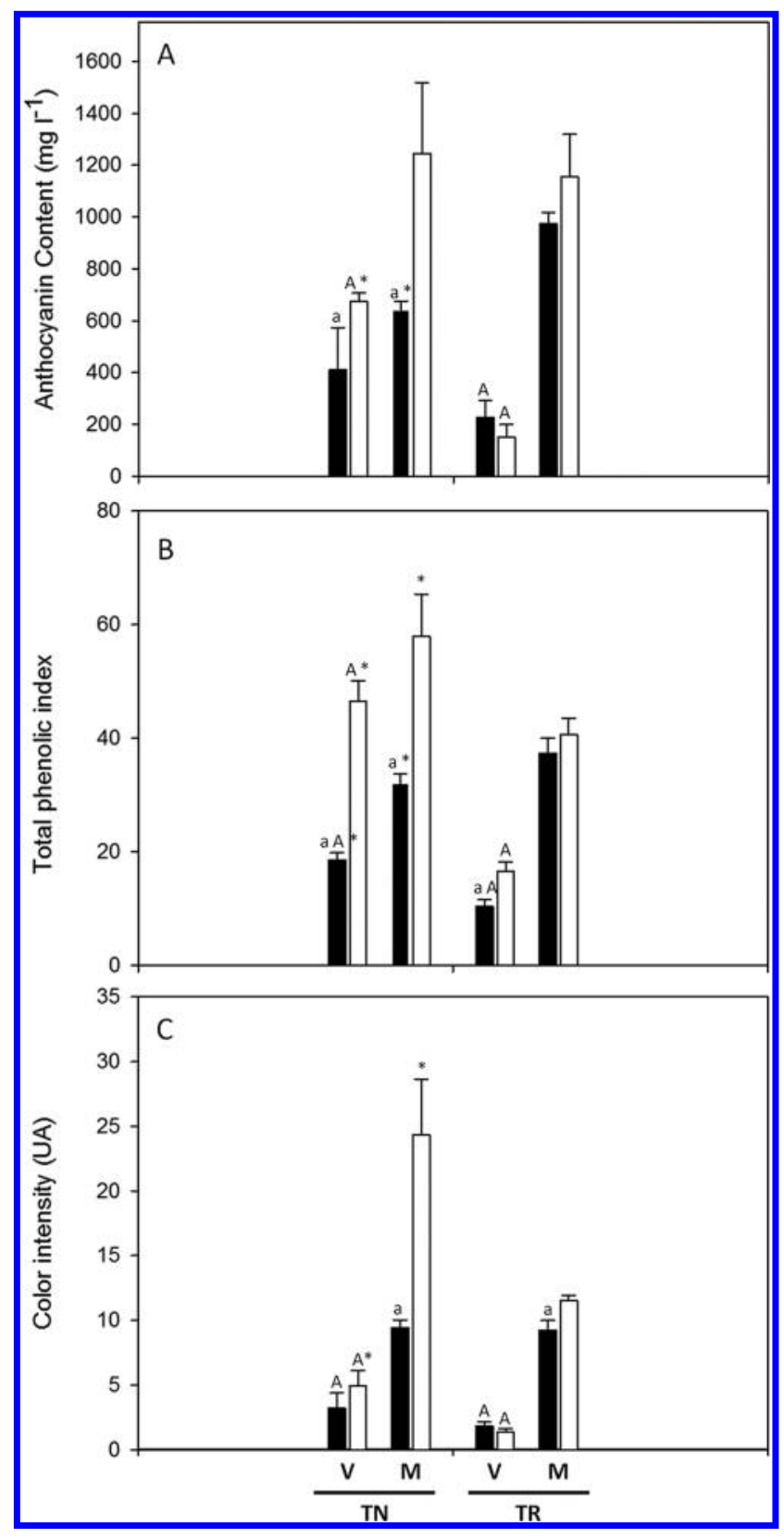

Figure 1. (A) Anthocyanin content, (B) total phenols and (C) color intensity of Touriga Nacional (TN) and Trincadeira (TR) berries at Veraison (V) and Maturation (M) grown in Full Irrigation (FI, black bars) or Non Irrigation (NI, white bars). Bars represent means \pm SD of three samples of 100 berries. A lower case letter indicates significant differences between treatments; a capital letter indicates significant differences between stages. An asterisk indicates significant differences between varieties, at $p<0.01$ significance.

given by the force rendered in penetration tests. In TN-NI, a higher force for berry deformation was necessary, while skin break force and energy were higher in TR-NI, decreasing from veraison to the maturation as expected (Table 2, see also Table S2). The Young modulus $\left(E_{\mathrm{sk}}\right)$ that represents the material resistance to axial deformation had the same trend as skin break force, revealing a decrease in the springiness of TR-NI berry skins (Table 2). Our results suggest that these specific properties may be influenced by the amount of phenolic compounds (Table S2).
The Pearson correlation between the berry texture attributes and $\mathrm{CW}$ composition showed significant negative correlations between skin break force and skin break energy with anthocyanin and total phenol contents. Noticeably, cellulose content was found to be positively correlated to the force needed to break the skin while lignin correlated to the energy applied to achieve rupture.

Sugar Composition in CW Fractions. Since major differences in cellulose and lignin between irrigation practices and varieties were observed at the maturation stage, only this stage was considered for berry skin CW fractionation. CDTA extracts polysaccharides that are less bound to the CW. The more tightly bound CW polysaccharides are extracted by increasing $\mathrm{KOH}$ molarity. The majority of polysaccharides were extracted in the alkaline fractions, particularly the $6 \mathrm{M} \mathrm{KOH}$, with the exception of TR-FI. Considering the responses of the varieties to the irrigation regimes, in TN-NI, weakly bound polysaccharides were shown to be more extractable than under full water availability. In TR-NI, more polysaccharides were extracted in the $6 \mathrm{M} \mathrm{KOH}$ fraction, suggesting a more tight binding to the $\mathrm{CW}$ (Figure 3). The majority of uronic acids (reflecting the pectin content) was extracted in the CDTA and $0.1 \mathrm{M} \mathrm{KOH}$ fractions, with higher amounts in the latter (Figure $4 A, B)$. No differences were observed between treatments or varieties. The analysis of the $\mathrm{CW}$ fractions by GC showed that the most abundant neutral monosaccharide present in all fractions was arabinose, followed by glucose, xylose, and galactose. The arabinose-, xylose-, and glucose-containing polysaccharides were in all cases higher in TR in all alkaline treatments, although in the $0.1 \mathrm{M} \mathrm{KOH}$ fraction, TR-NI samples showed decreased arabinose-containing polysaccharides when compared to the control (Figure 4B), which were shifted to the strong alkaline fraction (Figure 4C). For TN-NI, the $6 \mathrm{M} \mathrm{KOH}$ fraction showed a small but significant increase of arabinose-containing polysaccharides. The majority of xylose-containing polysaccharides were putatively tightly bonded to the CW since they only could be extracted by strong alkaline conditions. Conversely to TN, TR-NI was richer in xylose-containing polysaccharides (Figure 4C).

Changes in the Expression of Selected Key Genes Involved in Modification of the Berry CW. One way to access the effect of a stress on a given metabolic event is to understand the transcription of related genes. Figure 5 shows that water depletion gave rise to different gene expression patterns, some activated at veraison and others at maturation. As compared to $\mathrm{TR}, \mathrm{TN}$ had more responsive genes, most of them downregulated after water deficit in the two varieties. The expression of XTH genes was severely down-regulated at veraison on both varieties, with the exception of $V v X T H 14$ in TN. Conversely, at maturation, members of this family were not affected by the water shortage. At veraison, both PGs investigated were upregulated in TN while $V v P G 1$ in TR showed a 3-fold downregulation when compared to the control. In maturation, the majority of PGs were repressed, including VvPG6, which had a 7 fold repression compared to the control (Figure 5). The majority of EXPA gene expression had a similar downregulation at veraison. EXPA genes were more repressed at maturation (Figure 5). The expression of PME genes unraveled a higher number of members showing down-regulation under water scarcity in both TN and TR. As in the case of EXPA, these genes were more repressed at maturation. Interestingly, under water shortage, PMEI gene expression was shown to be generally not affected at veraison. At maturation in $\mathrm{TN}$, two 


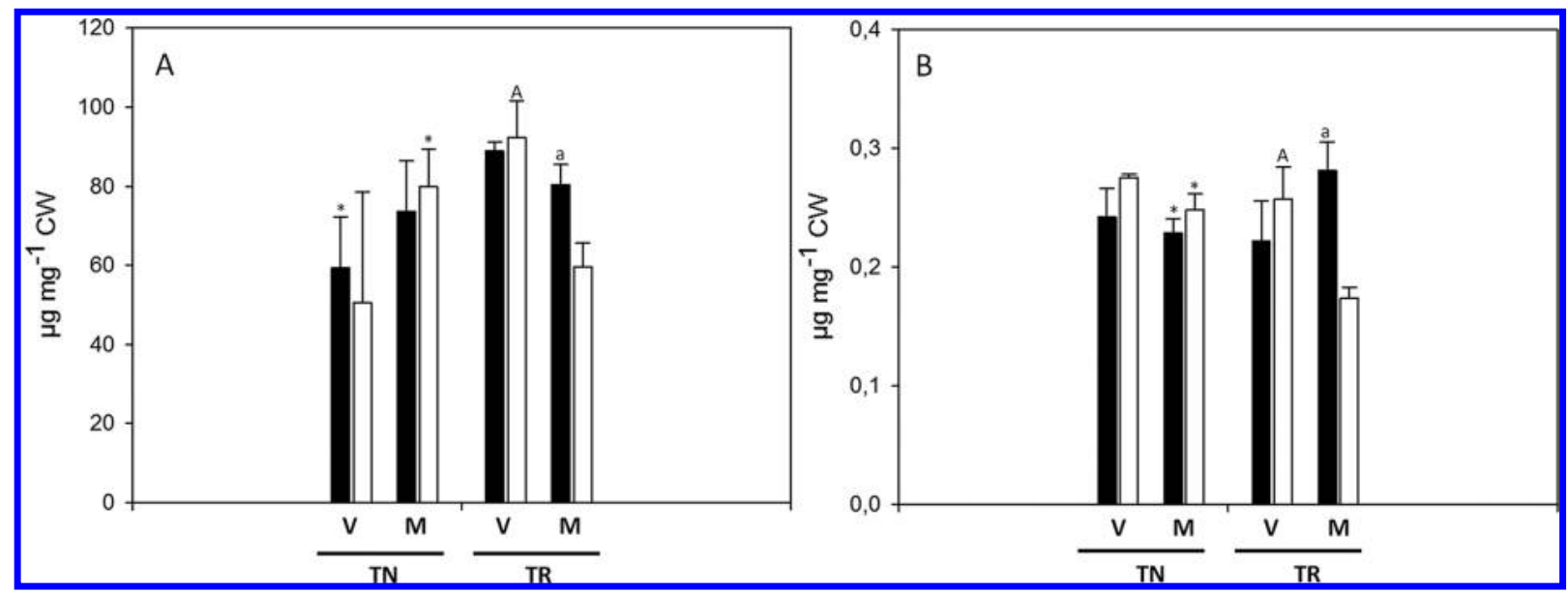

Figure 2. (A) Cellulose content and (B) lignin content of Touriga Nacional (TN) and Trincadeira (TR) berry skin CW at Veraison (V) and Maturation (M) grown in Full Irrigation (FI, black bars) or Non Irrigation (NI, white bars). Bars represent means of three samples \pm SD. Lower case letters indicate significant differences between treatments. Capital letters indicate significant differences between stages, and asterisks indicate significant differences between varieties, at $p<0.01$ significance.

Table 2. Berry Compression, Skin Break Force, Skin Break Energy, and Young's Modulus for Elasticity Parameters (Mean \pm Standard Deviation) of Touriga Nacional (TN) and Trincadeira (TR) Berries at Veraison (V) and Maturation (M) Grown in Full Irrigation (FI) or Non Irrigation $(\mathrm{NI})^{a}$

$\begin{array}{lcccccc}\text { Veraison } & & & \text { berry firmness }(\mathrm{N}) & \text { skin break force }(\mathrm{N}) & \text { skin break energy }(\mathrm{mJ}) & \text { Young's modulus for elasticity }\left(\mathrm{N} \mathrm{mm}^{-1}\right) \\ & \text { TN } & \text { FI } & 2.07^{\mathrm{a} *} \pm 0.62 & 4.75^{\mathrm{a}} \pm 0.65 & 3.82^{\mathrm{a}} \pm 1.1 & 2.85 \pm 0.62 \\ & & \text { NI } & 4.46^{*} \pm 0.71 & 3.40^{*} \pm 0.73 & 2.14^{\mathrm{A} *} \pm 0.79 & 2.87^{*} \pm 0.82 \\ & \text { TR } & \text { FI } & 3.54 \pm 0.39 & 5.08^{\mathrm{a}} \pm 0.79 & 4.85^{\mathrm{A}} \pm 1.26 & 3.11^{\mathrm{A}} \pm 0.83 \\ \text { Maturation } & & \text { NI } & 2.99 \pm 0.42 & 7.17^{\mathrm{A}} \pm 0.84 & 6.05^{\mathrm{A}} \pm 1.63 & 5.2^{\mathrm{A}} \pm 0.98 \\ & \text { TN } & \text { FI } & 1.03^{\mathrm{a} *} \pm 0.67 & 4.83 \pm 0.78 & 3.58 \pm 0.9 & 2.7^{\mathrm{a} *} \pm 0.43 \\ & & \text { NI } & 4.19^{*} \pm 0.37 & 4.50 \pm 0.75 & 3.58^{*} \pm 0.96 & 3.25^{*} \pm 0.64 \\ & \text { TR } & \text { FI } & 3.10 \pm 0.36 & 3.54^{\mathrm{a}} \pm 0.60 & 3.73^{\mathrm{a}} \pm 0.99 & 1.93^{\mathrm{a}} \pm 0.37 \\ & & \text { NI } & 2.49 \pm 0.46 & 4.97 \pm 0.60 & 4.85 \pm 0.91 & 2.51 \pm 0.31\end{array}$

${ }^{a}$ Lower case letters indicate significant differences between treatments. Capital letters indicate significant differences between stages, and asterisks indicate significant differences between varieties, at $p<0.01$ significance.

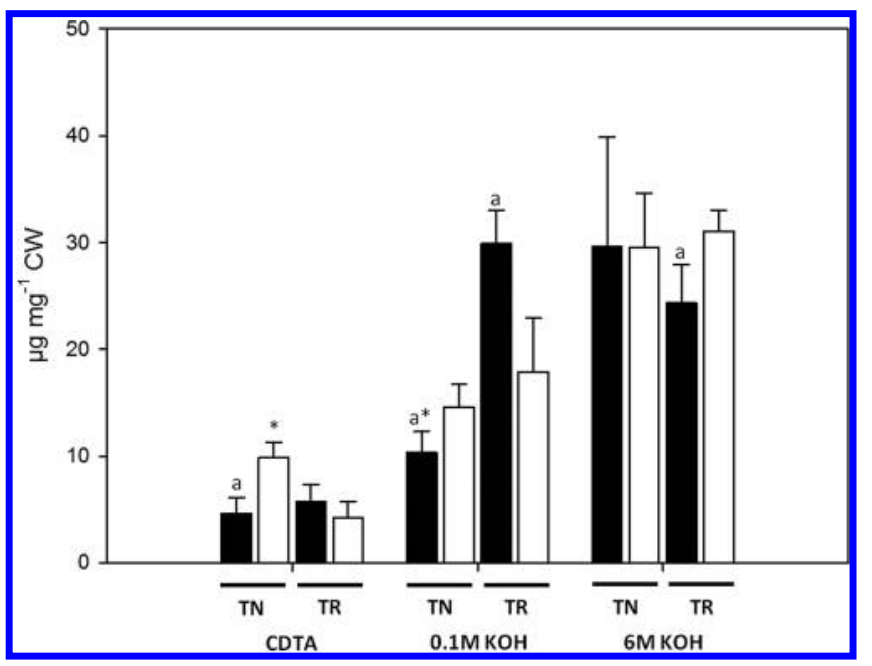

Figure 3. Total sugar quantification in $\mathrm{CW}$ fraction obtained from Touriga Nacional (TN) and Trincadeira (TR) berry skin CW at Maturation (M) grown in Full Irrigation (FI, black bars) or Non Irrigation (NI, white bars). Units are micrograms of glucose equivalents per millgram of $\mathrm{CW}$. Bars represent means of three samples \pm SD. Lower case letters indicate significant differences between treatments, and asterisks indicate significant differences between varieties, at $p<0.01$ significance. genes were down-regulated ( $V v P M E I 3$ and $V v P M E I 4)$, but the same $V v P M E I 3$ in TR was up-regulated with a fold change of 6 (Figure 5).

Data Integration. To obtain a global representation of all data collected at maturation, samples were graphically plotted in a reduced number of axis after multivariate analysis (Principal Component Analysis; PCA). Principal components 1 and 2 (PC1 and PC2) in combination explain 58.8\% of the total variation and could separate the samples according to the variety and water regime to which they were submitted. Replicates were generally closely clustered, demonstrating the accuracy of the analyses performed and the true biological basis of the measured dissimilarities. The results shown in Figure 6 reveal that PC1 clearly differentiates between varieties while PC2 separates the samples according to the treatments. According to the resultant eigenvectors calculated using the average values of the triplicates (Table S3), the variables that contributed more to PC1 separation were the higher amounts of arabinose- and galactose-containing polysaccharides extracted in the $0.1 \mathrm{M} \mathrm{KOH}$ fraction and xylose-containing polysaccharides collected in both alkaline solutions, and the lower relative transcription of $V v P M E I 1, V v P M E I 2, V v X T H 31$, and $V v X T H 15$ in the TR variety. PC2 separation was mainly explained by lower amounts of glucose-containing polymers extracted by $0.1 \mathrm{M} \mathrm{KOH}$ solutions, by mannose- and fucosecontaining polysaccharides present in the $6 \mathrm{M} \mathrm{KOH}$ solution 


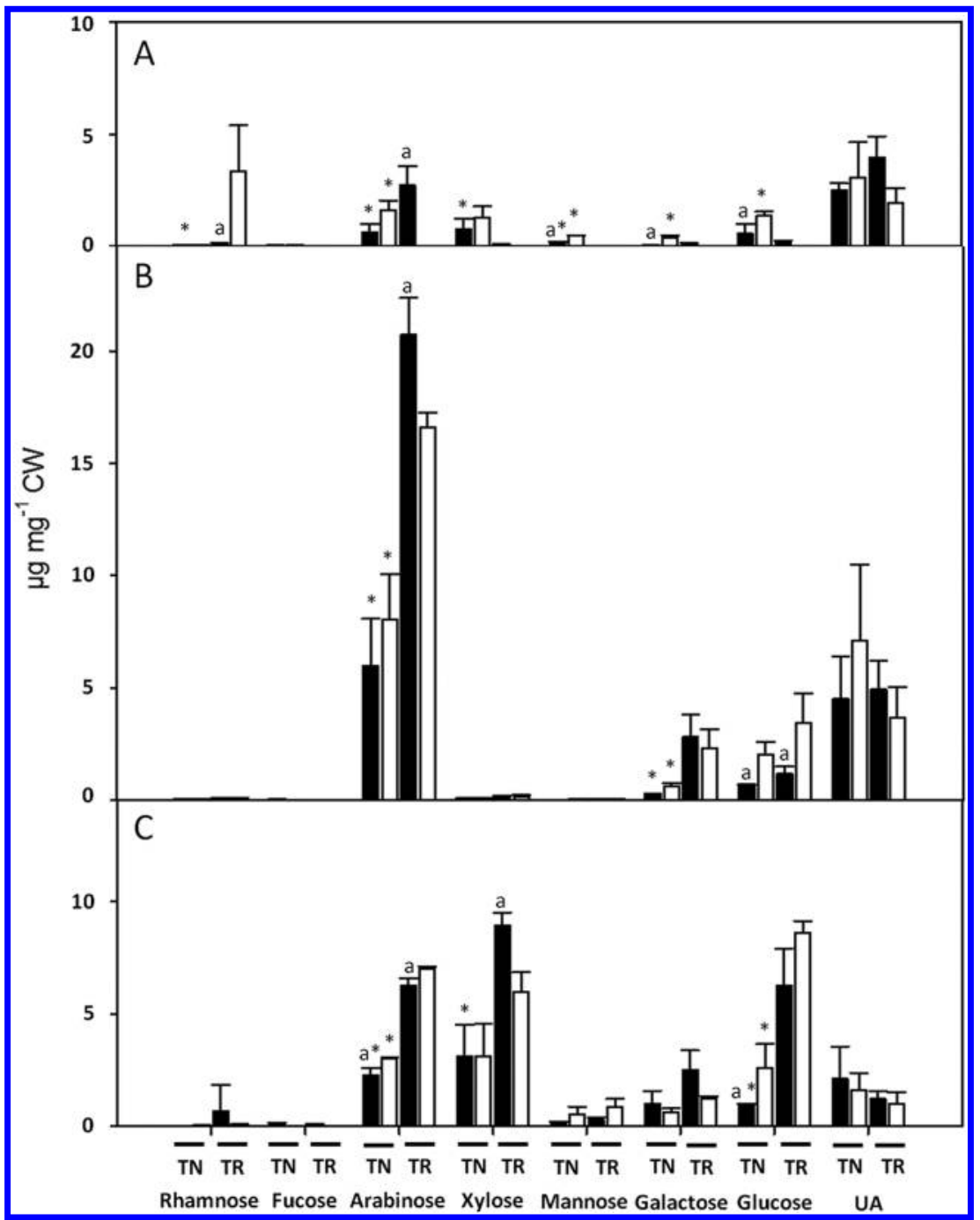

Figure 4. Monosaccharide composition of berry skin CW. (A) CDTA-soluble fraction, (B) $0.1 \mathrm{M} \mathrm{KOH}$-soluble fraction, and (C) $6 \mathrm{M} \mathrm{KOH}$-soluble fraction obtained by GC analysis and uronic acids levels measured by the m-hydroxybiphenyl assay in Touriga Nacional (TN) and Trincadeira (TR) berries at maturation grown in Full Irrigation (FI, black bars) or Non Irrigation (NI, white bars). Units are micrograms of each monosaccharide and galacturonic acid equivalents for uronic acids (UA) permilligram of CW. Bars represent means of three samples \pm SD. Lower case letters indicate significant differences between treatments, and asterisks indicate significant differences between varieties, at $p<0.01$ significance.

under the FI regime, and by the lower relative expression of two polygalacturonase genes, $V v P G 2$ and $V v P G 4$, in the control.

\section{DISCUSSION}

Water deficit during Vitis vinifera L. growth, like other abiotic stresses, is known to decrease growth and yield, ${ }^{64-66}$ impacting berry physical and chemical composition ${ }^{67}$ and, ultimately, influencing the sensorial quality of the final product. ${ }^{68}$ In this work, we assessed the influence of nonirrigation in comparison with water full conditions in berry characteristics, CW composition, and gene expression of two widespread Portuguese winegrape varieties, Touriga Nacional and Trincadeira, growing under Mediterranean conditions with Atlantic influence, to which some grapevines varieties are better adapted than others. ${ }^{69}$ The clear effects exerted by water deficit on berry characteristics (Table 1) confirm previous results showing that water deficiency results in an increase in anthocyanin concentration, ${ }^{70}$ and in total phenols (Figure $1){ }^{29}$ It is unsure whether the increase in total polyphenol content is purely due to the fluctuations in anthocyanin content or by the increase of other phenolic compounds including flavanols and proanthocyanidins. ${ }^{29}$ Moreover, the varietyspecific amount of anthocyanin observed is also in agreement with previous studies. ${ }^{71}$ The global CW results allowed an evident separation of both varieties and the imposed water regimes, as illustrated by the PCA plots (Figure 6). The separation in the two first components is mainly explained by the amount of monosaccharides extracted in distinct fractions, which suggest different polysaccharide linkages, and by CWrelated gene expression (Table S3).

Among the effects on CW, the alterations mostly associated with changes in composition and architecture are the berry texture characteristics. Texture analysis is a rapid and low-cost analytical technique that can be applied in viticulture and enology as a routine tool for monitoring grape quality. ${ }^{72}$ In our research, texture measurements were conducted with the objective of comparing the changes in mechanical properties of the berry and berry skin between the two cultivars under the water regimes imposed during grape development. Therefore, and since the assays were conducted with frozen/thawed grapes, the measurements do not describe fresh berries values 


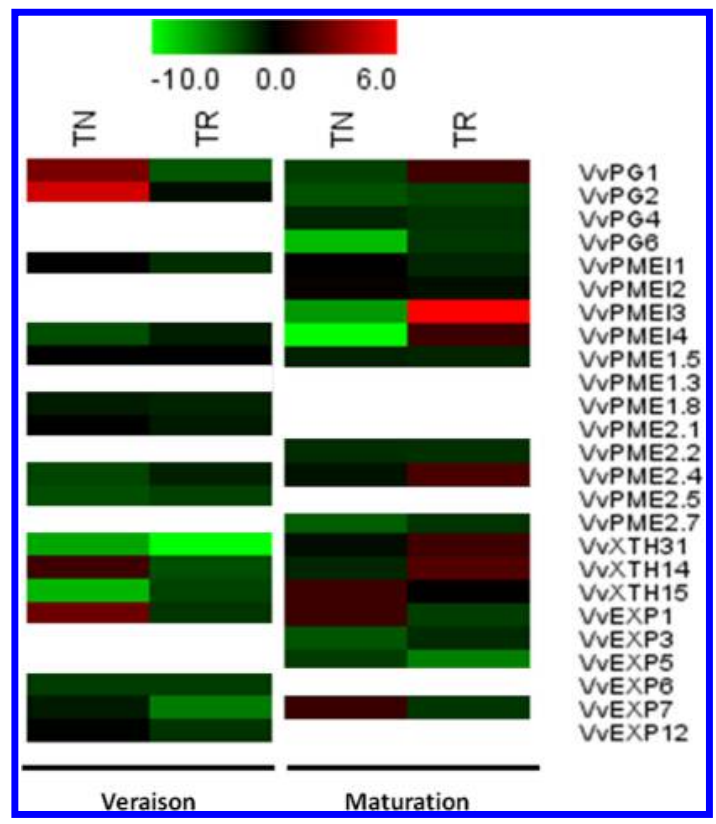

Figure 5. Heat-map of transcriptional responses to water shortage of $\mathrm{CW}$ modifying genes in $\mathrm{TN}$ and $\mathrm{TR}$ varieties at veraison and maturity. Color scale from green to red indicates $\log 2 \mathrm{NI} / \mathrm{FI}$ expression ratio from 10 -fold repression to 6-fold over transcription.

but clearly indicate that under our conditions the higher skin break force measured in TR-NI berries (Table 2) seems to be variety dependent, since TN break force was not affected by the water regime. Conversely, in TN-NI compression tests, higher forces were needed to attain the same berry deformation (Table 2). The increase in berry skin break force in TR-NI was also observed in stressed Mondeuse, Becuét, and Fumin grapes obtained during on-vine drying. ${ }^{73,74}$ Recent observations by Zsófi et al. ${ }^{67}$ in Kékfrankos grapes growing under greenhouse conditions suggest that skin break force increases significantly as a result of water deficit. Conversely, berry firmness measured as berry deformation by the compression test was decreased in TN-NI. As a whole, the skin break force and skin break energy correlated negatively with the amounts of berry secondary metabolites but positively with cellulose and lignin contents, respectively (Table S2). This suggests that the lower cellulose and lignin content verified after water deficiency contributes, although in different dimensions, to the alteration in the skin mechanical properties. The responses obtained so far corroborate the dependence on the variety and the environmental conditions. ${ }^{75,76}$ However, and taking advantage of the aftermost results with fresh berries from an experimental water regime similar but not equivalent to the one reported here, for full clarification, the presented results might be confirmed with fresh berries from the cultivars and under the experimental setup as applied in the present study.

Aiming at gaining a further insight on the basis of water deficit on polysaccharide differences, general CW composition was investigated in all samples. In this work, TR-NI showed reduced amounts in cellulose and lignin at maturation (Figure 2 ), which was accompanied by a marked reduction in berry size (Table 1). In the Muscat Gordo Blanco variety, Nunan et al. ${ }^{6}$ found that cellulose remained unaltered during ripening, putting forward the assumption that the decrease in TR may be a genotype-specific response to water availability. Conversely, the increased break force may be caused by CW polysaccharides besides cellulose since this polymer serves as a scaffold for the binding of other CW components. ${ }^{77}$ The shift of arabinose-containing polysaccharides from the $0.1 \mathrm{M} \mathrm{KOH}$ to $6 \mathrm{M}$ fraction in TR-NI (Figure 4) may indicate that

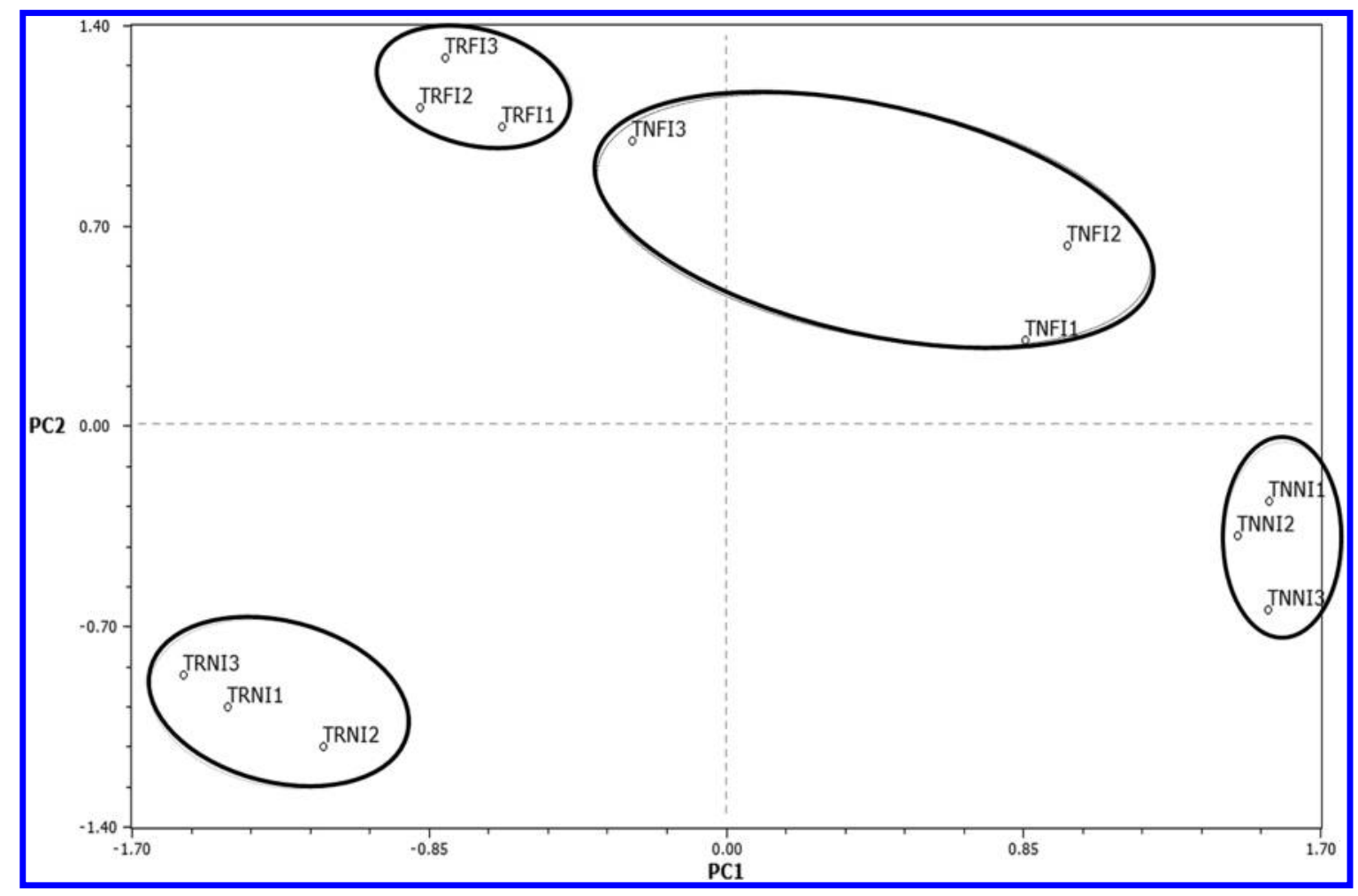

Figure 6. Principal component analysis (PCA) from 50 individual attributes measured at maturation. PC1 and PC2 explain, respectively, $35.3 \%$ and $25.6 \%$ of the total variation. 
rhamnogalacturonan-I (RGI) arabinosyl residues became more tightly bound into $\mathrm{CW}$ with water shortage. The presence of RGI decorated with arabinose rich side chains in water deficient conditions can work as CW plasticizers. $^{78}$ Under water shortage, arabinose and also galactose rich polymers are known to retain relatively longer mobility than other CW polymers filling the cavities created upon physical rearrangement of the $\mathrm{CW}^{79}$ The unusually high arabinan content (approximately $38 \mathrm{~mol} \%$ ) observed in the resurrection plant Myrothamnus flabellifolius ${ }^{80}$ further suggests an arabinose role for plants coping with water scarcity. Changes in pectin, break energy, and Young modulus $\left(E_{\text {sk }}\right)$ showed similar patterns to break force, again with a variety dependent behavior, skins becoming less elastic in the absence of water. From the correlation of $E_{\mathrm{sk}}$ values with total phenols content (Table S2), it can be inferred that the stiffening of the CW may contribute to the extractability of the phenolic compounds, as observed by Rolle et al. ${ }^{81}$ As referred to by other authors, Torchio et al. ${ }^{82}$ and Zsófi et al., ${ }^{67}$ an increase in elasticity was observed from veraison to ripening.

Gene expression of key candidate genes was considered to be differential when above a $\log 2 \pm 2$-fold change relative to the control and showed that all gene families investigated possess members that respond to water shortage (Figure 5). This complementary approach provided evidence that, although with a general pattern of down-regulation, responsive individual genes within each family were different depending on the stages. Exceptions were $V v P G 1$ and $V v P G 2$ at veraison in $\mathrm{TN}$ and $V v P M E I 3$ at maturation in TR that are up-regulated, both indicating changes in the pectic network of the CWs, which suggests different patterns of expression depending on the development stage, in accordance with Deluc et al. ${ }^{36}$ findings. According to PCA, concerning gene expression, the observed differences between varieties are putatively associated with differences in the inhibition of pectin methylesterification and in the expression of members of the xyloglucan endotransglycosylase/hydrolase (XTH) family. Pectins are embedded within the cellulose/hemicellulose network, forming a hydrophilic gel that imposes mechanical features to the wall such as regulation of the hydration status or defining the porosity and stiffness of the wall. ${ }^{83}$ PME activity can alter the degree and pattern of methyl esterification ${ }^{84}$ and, therefore, change the biophysical properties of the CW. Under water scarcity, the PME expression decreased, as also observed for some members of Sangiovese grapes. ${ }^{85}$ The maintenance in the degree of methyl esterification of pectins, as observed by Zoccatelli et al. ${ }^{85}$ in Sangiovese grapes, may lead in our case to the preservation of the CW structure, especially in TR, which is further supported by the penetration tests. At the biochemical level, the activity of PMEs is also regulated by PMEIs. Grimplet et al. ${ }^{37}$ reported modifications in the expression of a PMEI member, with downregulation at maturation, which is in agreement with the patter observed in this work in TN. Conversely, in TR its expression is upregulated, which contributes to the variety separation observed in the PCA analysis (Figure 6) This PME activity my change the pectin methyesterification degree. Changes in the degree of pectin methylation seem to be genotype-specific in Vitis, decreasing as ripening progresses in some cultivars like Cabernet Sauvignon, Merlot, and Monastrell, while it hardly changes in Syrah. ${ }^{4}$ This observation is in accordance with the differences found between TN and TR. A total of $15-25 \%$ of the hemicelluloses present in dicot primary $\mathrm{CW}$ are constituted by xyloglucans. ${ }^{12}$ The xyloglucan frame can be modified by XTHs, which can potentially have two distinct catalytic activities, namely transglycosylase (XET) or hydrolase (XEH).$^{86-88}$ These activities have been associated with the fruit softening that occurs during phase III of berry development and largely modulate CW loosening. ${ }^{6}$ In the present study, the lowest $V v X T H$ expression was observed at veraison, mainly in TR in result of water shortage. The low activity suggested by the down-regulation of XTH genes may lead to maintenance of the CW structure under water shortage. On the other hand, Deluc et al. $^{36}$ observed that XTH gene expression declined significantly along berry development.

The effect of distinct water regimes in gene expression was mainly due to the transcript abundance of polygalacturonases (PGs), which are CW-localized enzymes that cleave stretches of unesterified GalA residues and weaken the middle lamella. ${ }^{89}$ PG activity is known to accompany fruit ripening. ${ }^{90}$ The upregulation of $\mathrm{PG}$ at veraison and subsequent down-regulation at maturation is in agreement with Grimplet et al. ${ }^{37}$ under water deficit. In the pectin fraction of the grape mesocarp, both polysaccharide amounts and the neutral and acidic sugars of the water-soluble fraction temporally increase from before veraison to veraison stages, decreasing rapidly thereafter. ${ }^{18,91}$ The maintenance of the pectin level in response to water shortage, especially in the $6 \mathrm{M} \mathrm{KOH}$ fraction, may be partially explained by the low transcription levels of PMEs and PGs strengthening the CW and increasing the force necessary to break the skin. In the mesocarp, pectin and xyloglucan solubilization seems to occur at later stages of ripening while depolymerization events occur at earlier stages (reviewed by Goulao et al. ${ }^{92}$ ).

Expansins (EXPA) play also an important role in the CW loosening phenomenon via nonenzymatic mechanisms. ${ }^{93}$ Under water shortage, most expansin genes decreased expression during berry development, as observed by Grimplet et $\mathrm{al}^{37}$ Studies in postharvest Corvina withering berries, which can be considered as a water stress condition, ${ }^{35}$ demonstrated the alteration in expression of several expansin genes, namely the downregulation of $V v E X P A 1, V v E X P A 14$, and $V v E X P A 19$ during withering. Some authors propose that expansins are associated with pectin turnover, probably by regulating the contact between pectins and pectin-degrading enzymes. ${ }^{84}$ Brummell et al. $^{94}$ suggest the relation between different networks: the disassembly of the hemicellulosic network by expansin may be necessary for modifications in the pectins promoting physical accessibility of pectin substrates to PGs enzymes. From our results, it is possible to forward the hypothesis that water depletion has an indirect impact on pectins through the process proposed by Brummell et al. ${ }^{94}$

In summary, the overall results suggest differences in pectin metabolism between varieties in response to distinct water availability during growth under field conditions and support its involvement in distinct responses to environmental conditions. Water shortage affects grape berries by stiffening the CW, probably through alteration in PGs expression and pectin structure, in a way that significantly depends on the variety. Contrasting softening behaviors during ripening differs sufficiently between genotypes to allow discrimination regarding technological differences that can influence oenological practices.

\section{ASSOCIATED CONTENT}

\section{S Supporting Information}

List of primers used for RT-qPCR (Table S1), Pearson correlation values between berry texture parameter and berry 
CW components (Table S2), eigenvectors for each principal component (Table S3), fold change values of heat-map genes in Figure 5 (Table S4), precipitation at the vineyard throughout 2012 (Figure S1), and average soil humidity at different dates of the growing season (Figure S2) are available free of charge via the Internet at http://pubs.acs.org

\section{AUTHOR INFORMATION}

\section{Corresponding Author}

*Phone: 00351213653418. E-mail: samport@isa.ulisboa.pt.

\section{Present Address}

${ }^{\S}$ Enotria Winecellars, London, UK.

\section{Funding}

The research was funded by Fundação para a Ciência e Tecnologia (FCT): project PTDC/AGR-GPL/099624/2008, the Ph.D. research grant SFRH/BD/64047/2009 to J.C.F. and CBAA PestOE/AGR/UI0240/2011. This work also benefited from European project KBBE InnoVine (ref 311775) and the European COST Action FA1106 "QualityFruit."

\section{Notes}

The authors declare no competing financial interest.

\section{ACKNOWLEDGMENTS}

The field work was performed at PORVID Experimental Station (Pegões, PT), and the authors thank the president of its executive board, Prof. Antero Martins. The authors also like to acknowledge Prof. Isabel Sousa and Prof. Margarida Moldão for excellent discussions on biophysical and chromatography experiments.

\section{ABBREVIATIONS}

Act, Actin; CDTA, cyclohexane-trans-1.2-diamine$\mathrm{N}, \mathrm{N}, \mathrm{N}^{\prime}, \mathrm{N}^{\prime}$-tetraacetic acid sodium salt; CW, cell wall; EXPA, expansins; GC, gas chromatography; FI, full irrigation; $\mathrm{N}$, Newton; NI, no irrigation; PCA, principal component analysis; PGs, polygalacturonases; PMEs, pectin methylesterases; PMEIs, pectin methylesterases inhibitors; qPCR, real-time PCR; TIF, translation initiation factor eIF-3 subunit 4; TSS, total soluble solids in ${ }^{\circ}$ Brix; RGI, rhamnogalacturonan-I; TN, Touriga Nacional; TR, Trincadeira; XTH, xyloglucan endotransglycosylase/hydrolase

\section{REFERENCES}

(1) Kammerer, D.; Claus, A.; Carle, R.; Schieber, A. Polyphenol screening of pomace from red and white grape varieties (Vitis vinifera L.) by HPLC-DAD-MS/MS. J. Agric. Food Chem. 2004, 52, 43604367.

(2) Pinelo, M.; Del Fabbro, P.; Manzocco, L.; Nunez, M. J.; Nicoli, M. C. Optimization of continuous phenol extraction from Vitis vinifera byproducts. Food Chem. 2005, 92, 109-117.

(3) Montealegre, R. R.; Peces, R. R.; Vozmediano, J. L. C.; Gascuena, J. M.; Romero, E. G. Phenolic compounds in skins and seeds of ten grape Vitis vinifera varieties grown in a warm climate. J. Food Compos. Anal. 2006, 19, 687-693.

(4) Ortega-Regules, A.; Romero-Cascales, I.; Ros Garcia, J. M.; Bautista-Ortin, A. B.; Lopez-Roca, J. M.; Fernandez-Fernandez, J. I.; Gomez- Plaza, E. Anthocyanins and tannins in four grape varieties (Vitis vinifera L.) - Evolution of their content and extractability. J. Int. Sci. Vig. Vin. 2008, 42, 147-156.

(5) Rolle, L.; Siret, R.; Río Segade, S.; Maury, C.; Gerbi, V.; Jourjon, F. Instrumental Texture Analysis Parameters as Markers of TableGrape and Winegrape Quality: A Review. Am. J. Enol. Vitic. 2012, 63, $11-28$.
(6) Nunan, K. J.; Sims, I. M.; Bacic, A.; Robinson, S. P.; Fincher, G. $\mathrm{B}$. Changes in cell wall composition during ripening of grape berries. Plant Physiol. 1998, 118, 783-792.

(7) Brummell, D. A. Cell wall disassembly in ripening fruit. Funct Plant Biol. 2006, 33, 103.

(8) Dunlevy, J. D.; Kalua, C. M.; Keyzers, R. A.; Boss, P. K. The production of flavour \& aroma compounds in grape berries. Grapevine Molecular Physiology \& Biotechnology; Roubelakis-Angelakis, A. K., Ed.; Springer: Dordrecht, 2009; pp 293-340.

(9) Letaief, H.; Rolle, L.; Gerbi, V. Mechanical behavior of winegrapes under compression tests. Am. J. Enol. Viticult. 2008, 59, 323-329.

(10) Ortega-Regules, A.; Ros-García, J. M.; Bautista-Ortín, A. B.; López-Roca, J. M.; Gómez-Plaza, E. Changes in skin cell wall composition during the maturation of four premium wine grape varieties. J. Sci. Food Agric. 2008, 88, 420-428.

(11) Vicens, A.; Fournand, D.; Williams, P.; Sidhoum, L.; Moutounet, M.; Doco, T. Changes in polysaccharide and protein composition of cell walls in grape berry skin ( $\mathrm{Cv}$. Shiraz) during ripening and over-ripening. J. Agric. Food Chem. 2009, 57, 2955-2960.

(12) Carpita, N. C.; Gibeaut, D. M. Structural models of primary-cell walls in flowering plants - Consistency of molecular-structure with the physical-properties of the walls during growth. Plant J. 1993, 3, 1-30.

(13) Nunan, K. J.; Sims, I. M.; Bacic, A.; Robinson, S. P.; Fincher, G. $B$. Isolation and characterization of cell walls from the mesocarp of mature grape berries (Vitis vinifera). Planta 1997, 203, 93-100.

(14) Vidal, S. Polysaccharides from grape berry cell walls. Part I: tissue distribution and structural characterization of the pectic polysaccharides. Carbohydr. Polym. 2001, 45, 315-323.

(15) Lecas, M.; Brillouet, J. M. Cell-Wall composition of grape berry skins. Phytochemistry 1994, 35, 1241-1243.

(16) Saulnier, L.; Brillouet, J. M. An arabinogalactan protein from the pulp of grape berries. Carbohydr. Res. 1989, 188, 137-144.

(17) Bindon, K. A.; Smith, P. A.; Kennedy, J. A. Interaction between grape-derived proanthocyanidins and cell wall material. 1. effect on proanthocyanidin composition and molecular mass. J. Agric. Food Chem. 2010, 58, 2520-2528.

(18) Yakushiji, H.; Sakurai, N.; Morinaga, K. Changes in cell-wall polysaccharides from the mesocarp of grape berries during veraison. Physiol. Plant. 2001, 111, 188-195.

(19) Silacci, M. W.; Morrison, J. C. Changes in pectin content of cabernet-sauvignon grape berries during maturation. Am. J. Enol. Viticult. 1990, 41, 111-115.

(20) Chaves, M. M.; Maroco, J. P.; Pereira, J. S. Understanding plant responses to drought - from genes to the whole plant. Funct. Plant Biol. 2003, 30, 239-264.

(21) Matthews, M. A.; Nuzzo, V. Berry size and yield paradigms on grapes and wines quality. Acta Hortic. 2007, 423-435.

(22) Deluc, L. G.; Decendit, A.; Papastamoulis, Y.; Mérillon, J.-M.; Cushman, J. C.; Cramer, G. R. Water deficit increases stilbene metabolism in Cabernet Sauvignon Berries. J. Agric. Food Chem. 2011, 59, 289-297.

(23) Zarrouk, O.; Francisco, R.; Pinto-Marijuan, M.; Brossa, R.; Santos, R. R.; Pinheiro, C.; Costa, J. M.; Lopes, C.; Chaves, M. M. Impact of irrigation regime on berry development and flavonoids composition in Aragonez (Syn. Tempranillo) grapevine. Agr. Water Manage 2012, 114, 18-29.

(24) Dai, Z. W.; Ollat, N.; Gomes, E.; Decroocq, S.; Tandonnet, J. P.; Bordenave, L.; Pieri, P.; Hilbert, G.; Kappel, C.; van Leeuwen, C.; Vivin, P.; Delrot, S. Ecophysiological, genetic, and molecular causes of variation in grape berry weight and composition: a review. Am. J. Enol. Vitic. 2011, 62, 413-425.

(25) Greenspan, M. D.; Shackel, K. A.; Matthews, M. A. Developmental-changes in the diurnal water-budget of the grape berry exposed to water deficits. Plant, Cell Environ. 1994, 17, 811-820.

(26) Roby, G.; Matthews, M. A. Relative proportions of seed, skin and flesh, in ripe berries from Cabernet Sauvignon grapevines grown in a vineyard either well irrigated or under water deficit. Aust. J. Grape Wine Res. 2004, 10, 74-82. 
(27) Poni, S.; Lakso, A.; Turner, J.; Melious, R. Interactions of crop levels and late season water stress on growth and physiology of fieldgrown Concord grapevines. Am. J. Enol. Viticult. 1994, 45, 252-258.

(28) Ojeda, H.; Deloire, A.; Carbonneau, A. Influence of water deficits on grape berry growth. Vitis 2001, 40, 141-145.

(29) Castellarin, S. D.; Matthews, M. A.; Di Gaspero, G.; Gambetta, G. A. Water deficits accelerate ripening and induce changes in gene expression regulating flavonoid biosynthesis in grape berries. Planta 2007, 227, 101-12.

(30) Intrigliolo, D. S.; Castel, J. R. Interactive effects of deficit irrigation and shoot and cluster thinning on grapevine cv. Tempranillo. Water relations, vine performance and berry and wine composition. Irrig. Sci. 2011, 29, 443-454.

(31) Petrie, P. R.; Cooley, N. M.; Clingeleffer, P. R. The effect of post-veraison water deficit on yield components and maturation of irrigated Shiraz (Vitis vinifera L.) in the current and following season. Aust. J. Grape Wine Res. 2004, 10, 203-215.

(32) Koundouras, S.; Hatzidimitriou, E.; Karamolegkou, M.; Dimopoulou, E.; Kallithraka, S.; Tsialtas, J. T.; Zioziou, E.; Nikolaou, N.; Kotseridis, Y. Irrigation and rootstock effects on the phenolic concentration and aroma potential of Vitis vinifera $\mathrm{L}$. cv. Cabernet Sauvignon grapes. J. Agric. Food Chem. 2009, 57, 7805-7813.

(33) Jaillon, O.; Aury, J. M.; Noel, B.; Policriti, A.; Clepet, C.; Casagrande, A.; Choisne, N.; Aubourg, S.; Vitulo, N.; Jubin, C.; Vezzi, A.; Legeai, F.; Hugueney, P.; Dasilva, C.; Horner, D.; Mica, E.; Jublot, D.; Poulain, J.; Bruyere, C.; Billault, A.; Segurens, B.; Gouyvenoux, M.; Ugarte, E.; Cattonaro, F.; Anthouard, V.; Vico, V.; Del Fabbro, C.; Alaux, M.; Di Gaspero, G.; Dumas, V.; Felice, N.; Paillard, S.; Juman, I.; Moroldo, M.; Scalabrin, S.; Canaguier, A.; Le Clainche, I.; Malacrida, G.; Durand, E.; Pesole, G.; Laucou, V.; Chatelet, P.; Merdinoglu, D.; Delledonne, M.; Pezzotti, M.; Lecharny, A.; Scarpelli, C.; Artiguenave, F.; Pe, M. E.; Valle, G.; Morgante, M.; Caboche, M.; Adam-Blondon, A. F.; Weissenbach, J.; Quetier, F.; Wincker, P.; Public, F.-I. The grapevine genome sequence suggests ancestral hexaploidization in major angiosperm phyla. Nature 2007, 449, 463U5.

(34) Velasco, R.; Zharkikh, A.; Troggio, M.; Cartwright, D. A.; Cestaro, A.; Pruss, D.; Pindo, M.; FitzGerald, L. M.; Vezzulli, S.; Reid, J.; Malacarne, G.; Iliev, D.; Coppola, G.; Wardell, B.; Micheletti, D.; Macalma, T.; Facci, M.; Mitchell, J. T.; Perazzolli, M.; Eldredge, G.; Gatto, P.; Oyzerski, R.; Moretto, M.; Gutin, N.; Stefanini, M.; Chen, Y.; Segala, C.; Davenport, C.; Dematte, L.; Mraz, A.; Battilana, J.; Stormo, K.; Costa, F.; Tao, Q. Z.; Si-Ammour, A.; Harkins, T.; Lackey, A.; Perbost, C.; Taillon, B.; Stella, A.; Solovyev, V.; Fawcett, J. A.; Sterck, L.; Vandepoele, K.; Grando, S. M.; Toppo, S.; Moser, C.; Lanchbury, J.; Bogden, R.; Skolnick, M.; Sgaramella, V.; Bhatnagar, S. K.; Fontana, P.; Gutin, A.; Van de Peer, Y.; Salamini, F.; Viola, R. A High quality draft consensus sequence of the genome of a heterozygous grapevine variety. PLoS One 2007, 2.10.1371/journal.pone. 0001326

(35) Dal Santo, S.; Vannozzi, A.; Tornielli, G. B.; Fasoli, M.; Venturini, L.; Pezzotti, M.; Zenoni, S. Genome-wide analysis of the expansin gene superfamily reveals grapevine-specific structural and functional characteristics. PLoS One 2013, 8.10.1371/journal.pone.0062206

(36) Deluc, L. G.; Grimplet, J.; Wheatley, M. D.; Tillett, R. L.; Quilici, D. R.; Osborne, C.; Schooley, D. A.; Schlauch, K. A.; Cushman, J. C.; Cramer, G. R. Transcriptomic and metabolite analyses of Cabernet Sauvignon grape berry development. BMC Genomics 2007, 8, 429.

(37) Grimplet, J.; Deluc, L. G.; Tillett, R. L.; Wheatley, M. D.; Schlauch, K. A.; Cramer, G. R.; Cushman, J. C. Tissue-specific mRNA expression profiling in grape berry tissues. BMC Genomics 2007, 8, 187.

(38) Blazquez, M. A.; Lijavetzky, D.; Carbonell-Bejerano, P.; Grimplet, J.; Bravo, G.; Flores, P.; Fenoll, J.; Hellín, P.; Oliveros, J. C.; Martínez-Zapater, J. M. Berry flesh and skin ripening features in vitis vinifera as assessed by transcriptional profiling. PLoS One 2012, 7, e39547.
(39) Terrier, N.; Glissant, D.; Grimplet, J.; Barrieu, F.; Abbal, P.; Couture, C.; Ageorges, A.; Atanassova, R.; Leon, C.; Renaudin, J. P.; Dedaldechamp, F.; Romieu, C.; Delrot, S.; Hamdi, S. Isogene specific oligo arrays reveal multifaceted changes in gene expression during grape berry (Vitis vinifera L.) development. Planta 2005, 222, 832847.

(40) Waters, D. L. E.; Holton, T. A.; Ablett, E. M.; Lee, L. S.; Henry, R. J. cDNA microarray analysis of developing grape (Vitis vinifera cv. Shiraz) berry skin. Funct. Integr. Genomics 2005, 5, 40-58.

(41) Venturini, L.; Ferrarini, A.; Zenoni, S.; Tornielli, G. B.; Fasoli, M.; Dal Santo, S.; Minio, A.; Buson, G.; Tononi, P.; Zago, E. D.; Zamperin, G.; Bellin, D.; Pezzotti, M.; Delledonne, M. De novo transcriptome characterization of Vitis vinifera $\mathrm{cv}$. Corvina unveils varietal diversity. BMC Genomics 2013, 14, 41.

(42) Lopes, C. M.; Santos, T. P.; Monteiro, A.; Rodrigues, M. L.; Costa, J. M.; Chaves, M. M. Combining cover cropping with deficit irrigation in a Mediterranean low vigor vineyard. Sci. Hortic. 2011, 129, $603-612$.

(43) Santos, T. P.; Lopes, C. M.; Lucília, R. M.; de Souza, C. R.; Ricardo-da-Silva, J. M.; Maroco, J. P.; Pereira, J. S.; Manuela, C. M. Effects of deficit irrigation strategies on cluster microclimate for improving fruit composition of Moscatel field-grown grapevines. Sci. Hortic. 2007, 112, 321.

(44) Scholander, P.; Hammel, H.; Brandstreet, E.; Hemmingsen, E. Sap pressure in vascular plants. Science 1965, 148, 339-346.

(45) Dallas, C.; Laureano, O. Effects of $\mathrm{pH}$, sulphur dioxide, alcohol content, temperature and storage time on colour composition of a young Portuguese red table wine. J. Sci. Food Agric. 1994, 65, 477-485.

(46) Carbonneau, A.; Champagnol, F. Nouveaux systemes de culture integré du vignoble. In Programme AIR; 1993.

(47) Ribereau-Gayon, P.; Stonestreet, E. Le dosage des anthocyanes dans le vin rouge. Bull. Soc. Chim. 1965, 9, 2649-2652.

(48) Ribéreau-Gayon, P. Le dosage des composés phénoliques totaux dans les vins rouges. Chim. Anal. 1970, 52, 627-631.

(49) Walker, T. L.; Morris, J. R.; Threlfall, R. T.; Main, G. L.; Lamikanra, O.; Leong, S. Density separation, storage, shelf life and sensory evaluation of 'Fry' muscadine grapes. HortScience 2001, 36, 941-945.

(50) Rolle, L.; Giacosa, S.; Gerbi, V.; Novello, V. Comparative study of texture properties, color characteristics, and chemical composition of ten white table-grape varieties. Am. J. Enol. Vitic. 2011, 62, 49-56.

(51) Talmadge, K. W.; Keegstra, K.; Bauer, W. D.; Albersheim, P. The structure of plant cell walls: I. The macromolecular components of the walls of suspension-cultured sycamore cells with a detailed analysis of the pectic polysaccharides. Plant Physiol. 1973, 51, 158173.

(52) Fernandes, J. C.; García-Angulo, P.; Goulao, L. F.; Acebes, J. L.; Amâncio, S. Mineral stress affects the cell wall composition of grapevine (Vitis vinifera L.) callus. Plant Sci. 2013, 205-206, 111-120.

(53) Updegraff, D. M. Semimicro determination of cellulose inbiological materials. Anal. Biochem. 1969, 32, 420-424.

(54) Saeman, J. F.; Moore., W. E.; Millet, M. A. Sugar units present. Hydrolysis and quantitative paper chromatography. In CarbohydrateChemistry. Cellulose; Whistler, R. L., Ed.; Academic Press: New York, 1963; , Vol. 3, pp 54-69.

(55) Dische, Z. General color reactions. In Carbohydrate chemistry; Whistler, R. L., Ed. Academic: New York, 1962; pp 477-512.

(56) Hatfield, R. D.; Jung, H. J. G.; Ralph, J.; Buxton, D. R.; Weimer, P. J. A Comparison of the insoluble residues produced by the klason lignin and acid detergent lignin procedures. J. Sci. Food Agric. 1994, 65, $51-58$.

(57) Selvendran, R. R; Oneill, M. A. Isolation and analysis of cellwalls from plant-material. Method Biochem Anal 1987, 32, 25-153.

(58) Blumenkrantz, N.; Asboe-Hansen, G. New method for quantitative determination of uronic acids. Anal. Biochem. 1973, 54, 484-9.

(59) Albersheim, P.; Nevins, D. J.; English, P. D.; Karr, A. A method for the analysis of sugars in plant cell-wall polysaccharides by gas-liquid chromatography. Carbohydr. Res. 1967, 5, 340-345. 
(60) Fasoli, M.; Dal Santo, S.; Zenoni, S.; Tornielli, G. B.; Farina, L.; Zamboni, A.; Porceddu, A.; Venturini, L.; Bicego, M.; Murino, V.; Ferrarini, A.; Delledonne, M.; Pezzotti, M. The grapevine expression atlas reveals a deep transcriptome shift driving the entire plant into a maturation program. Plant Cell 2012, 24, 3489-3505.

(61) Coito, J. L.; Rocheta, M.; Carvalho, L.; Amâncio, S. Microarraybased uncovering reference genes for quantitative real time PCR in grapevine under abiotic stress. BMC Res. Notes 2012, 5, 220.

(62) Saeed, A. I.; Sharov, V.; White, J.; Li, J.; Liang, W.; Bhagabati, N.; Braisted, J.; Klapa, M.; Currier, T.; Thiagarajan, M.; Sturn, A.; Snuffin, M.; Rezantsev, A.; Popov, D.; Ryltsov, A.; Kostukovich, E.; Borisovsky, I.; Liu, Z.; Vinsavich, A.; Trush, V.; Quackenbush, J. TM4: A free, open-source system for microarray data management and analysis. Biotechniques 2003, 34, 374.

(63) Rohlf, F. J. NTSYSpc: Numerical Taxonomy System, ver. 2.20; Exeter Publishing, Ltd: Setauket, NY, 2008.

(64) Chaves, M. M.; Santos, T. P.; Souza, C. R.; Ortuño, M. F.; Rodrigues, M. L.; Lopes, C. M.; Maroco, J. P.; Pereira, J. S. Deficit irrigation in grapevine improves water-use efficiency while controlling vigour and production quality. Ann. Appl. Biol. 2007, 150, 237-252.

(65) Chaves, M. M.; Zarrouk, O.; Francisco, R.; Costa, J. M.; Santos, T.; Regalado, A. P.; Rodrigues, M. L.; Lopes, C. M. Grapevine under deficit irrigation: hints from physiological and molecular data. Ann. Bot. 2010, 105, 661-676.

(66) Flexas, J.; Galmés, J.; Gallé, A.; Gulías, J.; Pou, A.; Ribas-Carbo, M.; Tomàs, M.; Medrano, H. Improving water use efficiency in grapevines: potential physiological targets for biotechnological improvement. Aust. J. Grape Wine Res. 2010, 16, 106-121.

(67) Zsófi, Z.; Villangó, S.; Pálfi, Z.; Tóth, E.; Bálo, B. Texture characteristics of the grape berry skin and seed (Vitis vinifera L. cv. Kékfrankos) under postveraison water deficit. Sci. Hortic. 2014, 172, 176-182.

(68) Bucchetti, B.; Matthews, M. A.; Falginella, L.; Peterlunger, E.; Castellarin, S. D. Sci. Hortic. 2011, 128, 297-305.

(69) Schultz, H. R.; Stoll, M. Some critical issues in environmental physiology of grapevines: future challenges and current limitations. Aust. J. Grape Wine Res. 2010, 16, 4-24.

(70) Olle, D.; Guiraud, J. L.; Souquet, J. M.; Terrier, N.; Ageorges, A.; Cheynier, V.; Verries, C. Effect of pre- and post-veraison water deficit on proanthocyanidin and anthocyanin accumulation during Shiraz berry development. Aust. J. Grape Wine Res. 2011, 17, 90-100.

(71) Mazza, G. Anthocyanins in grapes and grape products. Crit. Rev. Food Sci. Nutr. 1995, 35, 341-371.

(72) Rolle, L.; Torchio, F.; Ferrandino, A.; Guidoni, S. Influence of wine-grape skin hardness on the kinetics of anthocyanin extraction. Int. J. Food Prop. 2012, 15, 249-261.

(73) Rolle, L.; Torchio, F.; Zeppa, G.; Gerbi, V. Relationship between skin break force and anthocyanin extractability at different ripening stages. Am. J. Enol. Viticult. 2009, 60, 93-97.

(74) Rolle, L.; Torchio, F.; Cagnasso, E.; Gerbi, V. Evolution of mechanical variables of winegrapes for icewine production during onvine drying. Ital. J. Food Sci. 2010, 22, 143-149.

(75) Rolle, L.; Gerbi, V.; Schneider, A.; Spanna, F.; Río Segade, S. Varietal Relationship between Instrumental Skin Hardness and Climate for Grapevines (Vitis vinifera L.). J. Agric. Food Chem. 2011, 59, 10624-10634.

(76) Río Segade, S.; Vázquez, E. S.; Orriols, I.; Giacosa, S.; Rolle, L. Possible use of texture characteristics of winegrapes as markers for zoning and their relationship with anthocyanin extractability index. Int. J. Food Sci. Technol. 2011, 46, 386-394.

(77) Lerouxel, O.; Cavalier, D. M.; Liepman, A. H.; Keegstra, K. Biosynthesis of plant cell wall polysaccharides - a complex process. Curr. Opin. Plant Biol. 2006, 9, 621-630.

(78) Harholt, J.; Suttangkakul, A.; Scheller, H. V. Biosynthesis of pectin. Plant Physiol. 2010, 153, 384-395.

(79) Tang, H. R.; Belton, P. S.; Ng, A.; Ryden, P. C-13 MAS NMR studies of the effects of hydration on the cell walls of potatoes and Chinese water chestnuts. J. Agric. Food Chem. 1999, 47, 510-517.
(80) Moore, J. P.; Nguema-Ona, E.; Chevalier, L.; Lindsey, G. G.; Brandt, W. F.; Lerouge, P.; Farrant, J. M.; Driouich, A. Response of the leaf cell wall to desiccation in the resurrection plant Myrothamnus flabellifolius. Plant Physiol. 2006, 141, 651-662.

(81) Rolle, L.; Río Segade, S.; Torchio, F.; Giacosa, S.; Cagnasso, E.; Marengo, F.; Gerbi, V. Influence of grape density and harvest date on changes in phenolic composition, phenol extractability indices, and instrumental texture properties during ripening. J. Agric. Food Chem. 2011, 59, 8796-8805.

(82) Torchio, F.; Cagnasso, E.; Gerbi, V.; Rolle, L. Mechanical properties, phenolic composition and extractability indices of Barbera grapes of different soluble solids contents from several growing areas. Anal. Chim. Acta 2010, 660, 183-189.

(83) Peaucelle, A.; Braybrook, S.; Höfte, H. Cell wall mechanics and growth control in plants: the role of pectins revisited. Front. Plant Sci. 2012, 3.10.3389/fpls.2012.00121

(84) Jolie, R. P.; Duvetter, T.; Van Loey, A. M.; Hendrickx, M. E. Pectin methylesterase and its proteinaceous inhibitor: a review. Carbohydr. Res. 2010, 345, 2583-2595.

(85) Zoccatelli, G.; Zenoni, S.; Savoi, S.; Dal Santo, S.; Tononi, P.; Zandonà, V.; Dal Cin, A.; Guantieri, V.; Pezzotti, M.; Tornielli, G. B. Skin pectin metabolism during the postharvest dehydration of berries from three distinct grapevine cultivars. Aust. J. Grape Wine Res. 2013, 19, 171-179.

(86) Fry, S. C.; Smith, R. C.; Renwick, K. F.; Martin, D. J.; Hodge, S. K.; Matthews, K. J. Xyloglucan endotransglycosylase, a new wallloosening enzyme-activity from plants. Biochem. J. 1992, 282, 821828.

(87) Rose, J. K. C.; Braam, J.; Fry, S. C.; Nishitani, K. The XTH family of enzymes involved in xyloglucan endotransglucosylation and endohydrolysis: Current perspectives and a new unifying nomenclature. Plant Cell Physiol. 2002, 43, 1421-1435.

(88) Nishitani, K. T.; Tominaga, R. Endo-xyloglucan transferase, a novel class of glycosyltransferase that catalyses transfer of a segment of xyloglucan molecule to another xyloglucan molecule. J. Biol. Chem. 1992, 267, 21058-21064.

(89) Brummell, D. A.; Harpster, M. H. Cell wall metabolism in fruit softening and quality and its manipulation in transgenic plants. Plant Mol. Biol. 2001, 47, 311-40.

(90) Cabanne, C.; Doneche, B. Changes in polygalacturonase activity and calcium content during ripening of grape berries. Am. J. Enol. Viticult. 2001, 52, 331-335.

(91) Silacci, M. W.; Morrison, J. C. Changes in pectin content of Cabernet Sauvignon grape berries during maturation. Am. J. Enol. Viticult. 1990, 41, 111-115.

(92) Goulao, L. F.; Fernandes, J. C.; Lopes, P.; Amâncio, S. Tackling the Cell Wall of the Grape Berry. In The biochemistry of the grape berry; Gerós, H. C., Delrot, S., Eds.; Bentham Science Publishers: 2012; pp $172-193$.

(93) Sampedro, J.; Cosgrove, D. J. The expansin superfamily. Genome Biol. 2005, 6.242 10.1186/gb-2005-6-12-242

(94) Brummell, D. A.; Harpster, M. H.; Civello, P. M.; Palys, J. M.; Bennett, A. B.; Dunsmuir, P. Modification of expansin protein abundance in tomato fruit alters softening and cell wall polymer metabolism during ripening. Plant Cell 1999, 11, 2203-2216. 